\title{
The biological control of seed-borne Alternaria brassicicola of cruciferous plants with a powdery preparation of Streptomyces sp.
}

\author{
TAHVONEN, R. and AVIKAINEN, H. \\ Department of Plant Pathology, Agricultural Research Centre, \\ SF-31600 JOKIOINEN, Finland
}

\begin{abstract}
The effectiveness of a powdery preparation of a Streptomyces sp. isolate as a seed dressing agent against seed-borne Alternaria brassicicola on different Brassica species was investigated in the study. The preparation was made by freeze-drying and milling the biomass produced in a fermentor into a form suitable for use as a dusting agent.

Seed dressing was $80-90 \%$ successful in controlling damping-off from seeds artificially infected with $A$. brassicicola. The effectiveness of dressing remained unchanged on seeds stored under dry conditions for 5-6 weeks, but subsequently decreased slowly and was ca. 50\% six months after dusting. Streptomyces dressing controlled, in a manner comparable to chemical dressing with thiram, damping-off caused by Alternaria fungi on seedlings which were grown from commercial seed lots of different origin. The results of biological control of dampingoff did not vary in the peat lots of different origin whose natural disease suppressivity varied considerably. The control result was the same or better than chemical dressing with thiram. The acidity of the substrate $(\mathrm{pH} 4.8-8.6)$ had no effect on the effectiveness of biological control. The results obtained against Alternaria damping-off were the same in other substrates - clay, fine sand and mull - as in peat.
\end{abstract}

Index words: Streptomyces sp. Alternaria brassicicola, biological control, Brassica sp.

\section{Introduction}

An isolate of Streptomyces sp., obtained from light-coloured, Finnish Sphagnum horticultural peat, has proved to be a potential biological control agent against plant pathogens (TAHVONEN 1982 a, 1982 b, TAHVONEN and Uoti 1983, TAHVONEN 1985), and especially effective against seed-borne Alternaria on cruciferous plants. A. brassicicola is the most common seed-borne pathogen of Brassica sp. throughout the world (NeERGAARD 1945). It is also common and the most serious seed-borne damping-off fungus on cruciferous plants in Finland (TAHVONEN 1979), and is routinely controlled by chemical dusting with thiram (TAHVONEN 1985).

A research programme into the practical application of Streptomyces sp. isolated from peat was started at the beginning of 1985 . 
A dry, powdery preparation in which the number of living particles was of the same order of magnitude as in the spore suspensions used in earlier experiments (TAHVONEN 1982 b), was developed by Kemira Co. The dry, powdery preparation was given the commercial name "Mycostop".

The aim of this study was to determine the effectiveness of the powdery Streptomyces preparation as a dressing agent in the control of Alternaria on cruciferous plants. The study was carried out at the Department of Plant Pathology, Agricultural Research Centre, during 1985-86.

\section{Material and methods}

A powdery preparation suitable for use as a seed dressing agent was prepared from a Streptomyces griseoviridis Anderson et al. isolate. Following culture in a fermentor, the cell mass was separated from the culture medium by centrifugation and then freeze-dried. Compounds designed to improve adhesion to the seeds and to maintain the vitality of the dry preparation, were added in connection with drying and milling. The final product contained $10^{8}-10^{9}$ living particles $/ \mathrm{g}$. Details of the manufacture of the preparation are not given here.

Preliminary and methodological tests were carried out on "Erfurter 291" or "Suuri Tanskalainen" cauliflower seeds, which were artificially infected with $A$. brassicicola in order to ensure an even degree of infection (TAHVONEN 1982 b). Commercial lots of cruciferous seed with a wide range of natural Alternaria infection (Fig. 4) were obtained from the State Seed Testing Institute and from a number of commercial seed suppliers. Ten lots of cabbage seed, 8 lots of cauliflower, and 9 lots of other Brassica species and their varieties were tested. A number of Chinese cabbage, swede and turnip seed lots were also included, but their results are not presented here because the degree of infection of the seeds was too low from the point of view of the experiment.
The seeds were dressed by carefully shaking them together with the dusting agent in a glass jar. When small lots of seeds were to be treated, a small batch was first dressed in order to ensure that there was a constant amount of the preparation on the wall of the jar. The seeds used in the experiment depicted in Fig. 2 were coated by a special method developed at Kemira Co's Vaasa factory in order to ensure that all the added amount of dressing agent had adhered to the seeds. According to tests carried out by Kemira Co, adhesion of the preparation in the other experiments varied from $50-70 \%$. In addition to undressed controls, the experiments also included undressed uninfected controls and a chemical control with a thiram dressing of $4 \mathrm{~g} / \mathrm{kg}$ on naturally infected seeds.

Retention of the dressing effectiveness on seeds stored under dry conditions was studied over a period of $0-18$ weeks after dressing. The dressed seeds were stored in the dark at $+5{ }^{\circ} \mathrm{C}$ and at $+20^{\circ} \mathrm{C}$. Since the storage temperature did not effect the effectiveness of control, the results presented in Figs. 1 and 2 are the means of two test factors.

In order to test the effect of substrate $\mathrm{pH}$ on the effectiveness of the Streptomyces isolate, the peat was limed with varying amounts of dolomite limestone and calcium hydroxide. The $\mathrm{pH}$ of the substrate following this treatment, as determined from a $0.02 \mathrm{~N} \mathrm{CaCl}_{2}$ extract, can be seen in Fig. 5. The effect of soil type on the effectiveness of the dressing agent was tested using the 6 different substrates listed in Table 2. In addition, the effectiveness of Streptomyces dressing was tested in 12 non-disinfected peat lots of different origin (Fig. 6).

Unless otherwise stated in connection with the results or in the tables, the seeds were sown in steam-disinfected light-coloured Sphagnum peat, which was given a basic fertilization of $10 \mathrm{~g}$ dolomite limestone/1, and $1.5 \mathrm{~g}$ of Peat Super Y fertilizer/l following steam disinfection. The seedlings were raised in 11 plastic pots or in $30 \times 40 \mathrm{~cm}$ plastic boxes. There were three or four replications, each replication 
Effect of Streptomyces seed treatment

on Alternaria damping-off

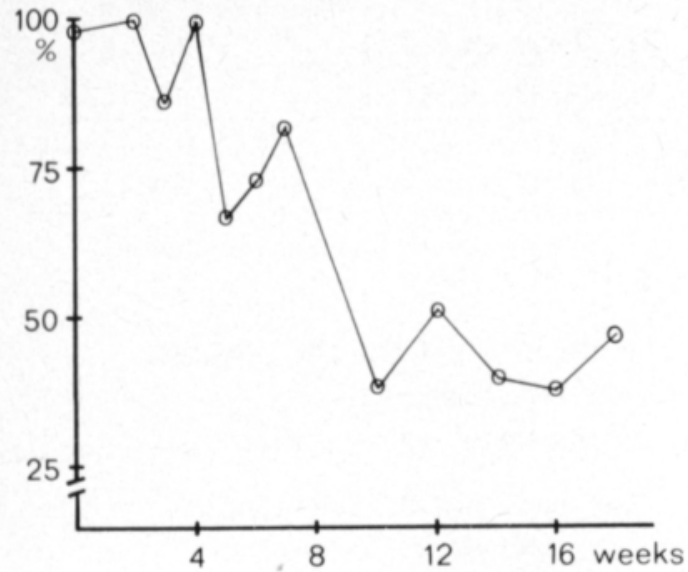

Time from seed treatment to sowing

Fig. 1. Retention of Streptomyces seed dressing $(15 \mathrm{~g} / \mathrm{kg})$ effectiveness on seed artificially infected with Alternaria brassicicola in seedling experiments.
Effect of Streptomyces seed treatment

on Alternaria damping-off

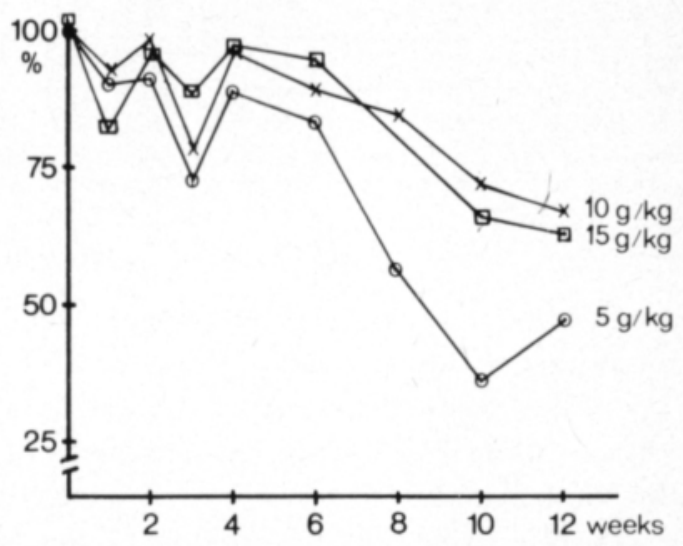

Time from seed treatment to sowing

Fig. 2. Effectiveness of Streptomyces seed dressing on seed artificially infected to different extents with Alternaria brassicicola. consisting of 50 seeds. The seedlings were grown from seed in thermostatically controlled greenhouses at $18-20{ }^{\circ} \mathrm{C}$ under artificial illumination of 8000 lux. This meant that the lots raised at different times were grown under as exactly the same conditions as possible. In addition to the substrate tests, $4 \times 25$ naturally infected seeds were sown on water agar in $9 \mathrm{~cm}$ petri dishes. The degree of fungal infection of the seedlings was determined under the microscope, as well as the mortality rate, two weeks after the seeds had been sown.

The degree of damping-off infection was determined on the seedlings at the end of the substrate experiments using the scale $0-2$, where $0=$ healthy, 1 = slightly infected, 2 = dead or non-viable. In addition, the fresh weight of those seedlings which had developed from naturally infected seed was determined. These results are not presented here because there were no differences in the weights of the healthy seedlings between different dusting treatments, and the dryweight results for the infected seedlings were correlated with the degree of infection.
The infection index, viable seedling $\%$ (which includes healthy + slightly infected seedlings as a $\%$ of the number of seeds sown), and the control effectiveness \% (calculated from the formula $(\mathrm{A}-\mathrm{B}):(\mathrm{C}-\mathrm{B}) \times$ 100 , where $A$ is the infection index or vitality of the dressed seedlings, B that of the infected control and $\mathrm{C}$ that of the healthy control), are presented in the tables. Where necessary, the statistical significance of the results has been tested using variance analysis.

\section{Results}

Control of Alternaria damping-off with the Streptomyces preparation

Dressing the seeds with the Streptomyces preparation controlled artificial infection by seed-borne $A$. brassicicola. Dressing levels greater than $5 \mathrm{~g} / \mathrm{kg}$ seed had no effect on the effectiveness of dressing when sowing was done on the same day or within one week after dressing (Table 1, Fig. 2). A dressing level of $1 \mathrm{~g} / \mathrm{kg}$ seed resulted in significantly more healthy seedlings than the control, but was 
Table 1. Effect of the Streptomyces seed dressing dose on damping-off caused by Alternaria brassicicola on cauliflower raised in peat.

\begin{tabular}{lccccccc}
\hline \multirow{2}{*}{ Seed } & \multicolumn{7}{c}{ Streptomyces dose, $\mathrm{g} / \mathrm{kg}$ seed } \\
& 0 & 1 & 5 & 10 & 15 & 20 \\
\cline { 2 - 8 } & \multicolumn{7}{c}{ Viable seedlings, $\%$} \\
\hline Alternaria-infected & 30 & 62 & 90 & 94 & 90 & 86 & $\mathrm{~F}=139.6^{* * *}$ \\
Non-infected & 88 & - & 86 & 78 & - & 86 & $\mathrm{~F}=1.0$ \\
\hline
\end{tabular}

however poorer than dressing levels of $5 \mathrm{~g} / \mathrm{kg}$ or more. Dressing had no effect on the number of healthy seedlings nor the dry weight in the case of healthy, uninfected seed in any of the experiments.

The effectiveness of the Streptomyces powder remained unchanged on dressed seed stored for a period of $4-6$ weeks. The treatment was still effective on dressed seed stored for as long as 18 weeks, although less effective than after a short storage period (Figs. 1 and 2). Higher dressing levels of 10 and $15 \mathrm{~g} / \mathrm{kg}$ seed had a better effectiveness after 6 weeks storage than the level of $5 \mathrm{~g} / \mathrm{kg}$ seed (Fig. 2).

Dressing naturally infected Brassica sp. seeds with the Streptomyces powder completely controlled damping-off on the peat substrate. The result was fully comparable with that obtained with chemical dressing with thiram. A slight damage was found at the base of seedlings grown from some dressed seed lots. This was insignificant from the point of view of seedling growth, and in fact occurred with both biological and chemical dressing. The effect of dressing on A. brassicicola on seeds grown on the water agar medium also proved to be effective (Fig. 4). Both $5 \mathrm{~g}$ and $10 \mathrm{~g}$ of the Streptomyces preparation $/ \mathrm{kg}$ seed were sufficent to prevent the growth of the pathogen. Almost the same result was obtained with thiram dressing, but the effectiveness of chemical dressing was lost in the case of some seed lots and there was more Alternaria in these petri dishes than in seeds dressed with Streptomyces. The mortality of the seedlings on the agar medium was completely dependent on the Alternaria content.
The effect of $\mathrm{pH}$ and the substrate on the effectiveness of the Streptomyces preparation

The acidity of the substrate had no effect on the ability of Streptomyces to control Alternaria damping-off over the $\mathrm{pH}$ range $4.8-8.6$ (Fig. 5). There was more dampingoff on undressed seeds grown on acidic or slightly alkaline substrates than on a neutral substrate. However, the result was not statistically significant.

Streptomyces dressing controlled dampingoff on cauliflower on both the organic and inorganic substrates in a similar fashion to thiram dressing. There was no difference as regards the control of Alternaria between the steam-sterilized and unsterilized substrate (Table 2).

A. brassicicola caused damping-off to a varying degree on the peat substrate of different origins. Some of the peat lots inhibited Alternaria by $60-70 \%$ compared to the steam-sterilized peat or peat lots susceptible to this pathogen. Streptomyces dressing controlled damping-off in the different peat lots in the same way as chemical dressing with thiram despite the natural antipathogenic properties of the substrate. Dressing resulted in similar numbers of viable seedlings as were obtained when healthy seeds were used (Fig. 6).

\section{Discussion}

The powdery preparation made from Streptomyces griseoviridis bacteria proved to be highly effective in controlling seed-borne Alternaria brassicicola growing on cruciferous 
plants. This is in good agreement with the results of earlier experiments in which a spore suspension was used in treating the seeds

Disease index
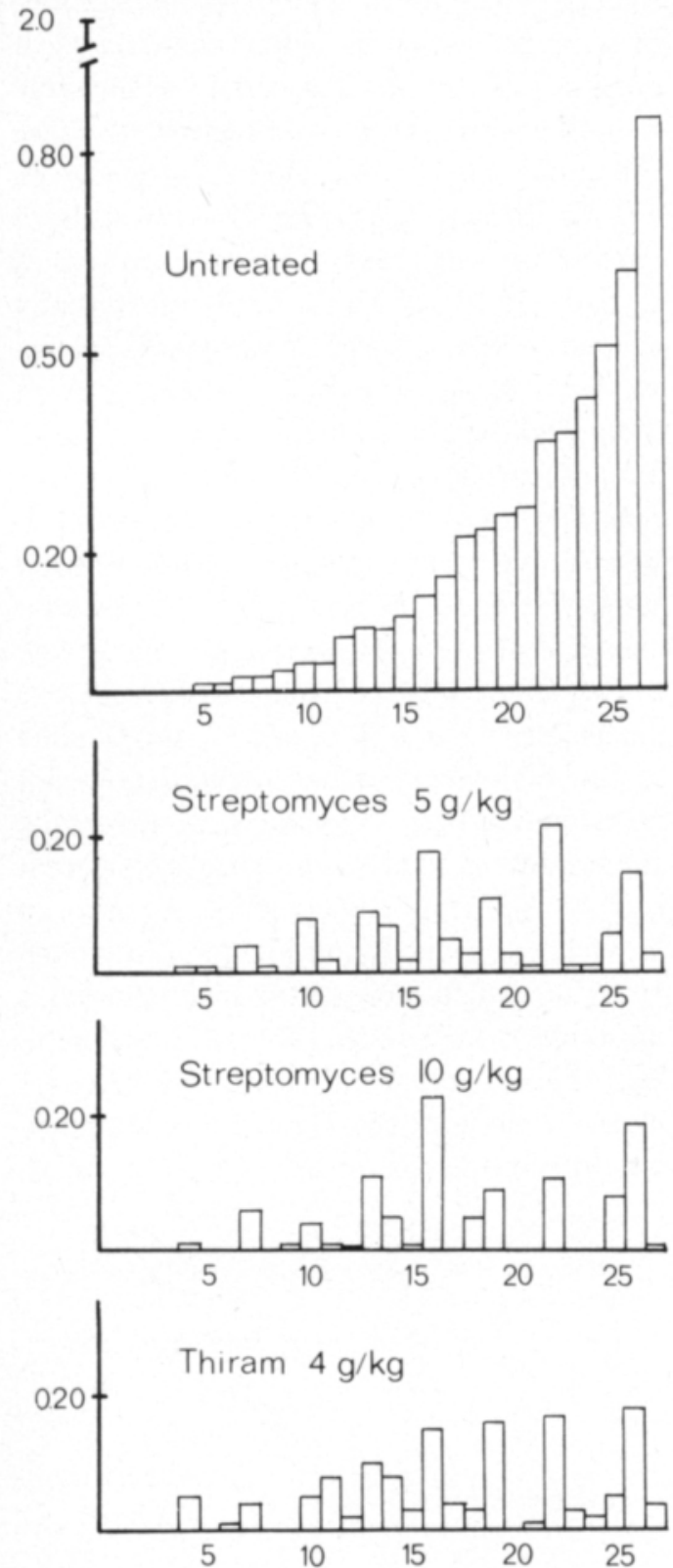

\section{Seed lots}

Fig. 3. Effect of seed dressing with thiram or different amounts of the Streptomyces preparation on the control of seed-borne Alternaria brassicicola in different lots of Brassica sp. seed. Naturally infected seed.
(TAHVONEN $1982 \mathrm{~b}$ ). The effectiveness against damping-off was the same on both artificially infected and naturally infected seed. On the

Alternaria content of seeds
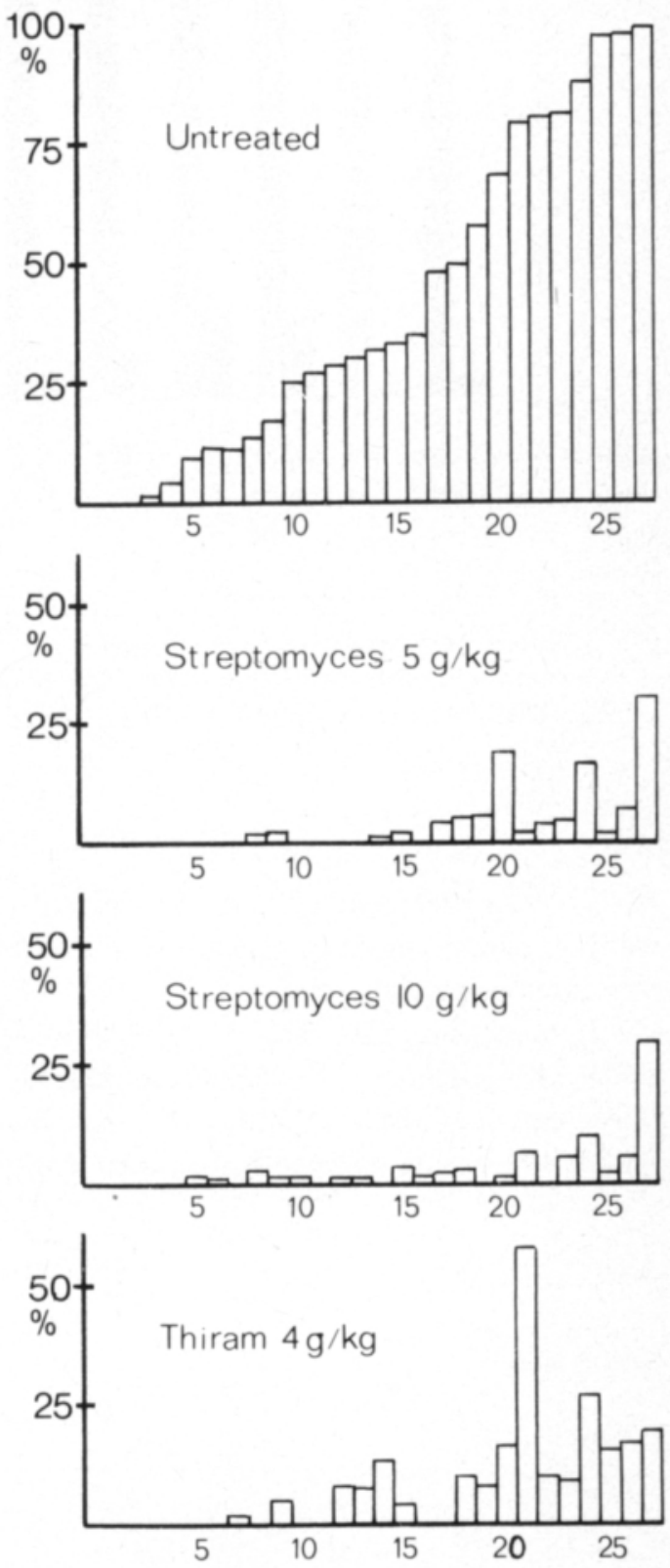

Seed lots

Fig. 4. Effect of seed dressing with thiram or different amounts of the Streptomyces preparation on the Alternaria brassicicola content of seedlings grown from seed on agar for two weeks. Different seed lots. 


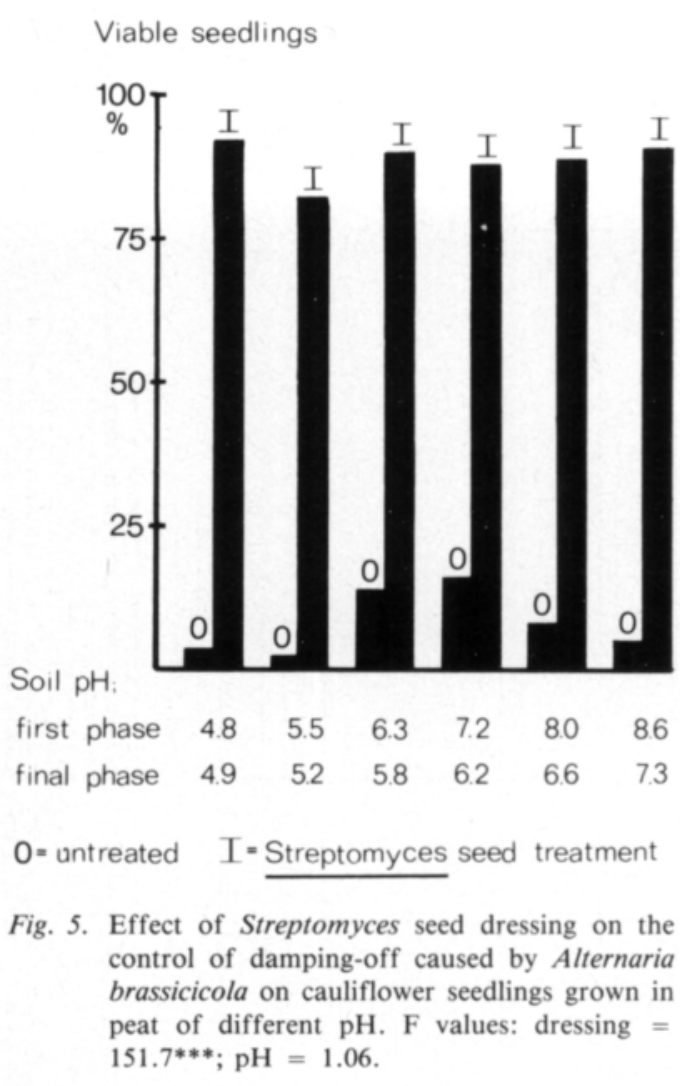

basis of this, the results obtained with artificially infected seed can be generalized to cover normal commercial seed.

Alternaria fungi (A. brassicae, A. brassicicola, A. raphani) are the most common seedborne pathogens on cruciferous plants (NEERGAARD 1945), and are controlled chemically by dressing the seed with dithiocarbamate (Heinze 1974, Dixon 1981) or iprodione and fempropimorph fungicides (MAUDE et al. 1984). In the present experiments biological control of naturally infected seed was equally successful with the Streptomyces preparation, or in some cases even better, than chemical dressing with thiram. The result was the same in both in vitro and in vivo experiments. Since the antagonistic effect of $S$. griseoviridis against different pathogens is very wide in vitro (TAHVONEN 1982 a), there is no reason to assume that it would behave differently against $A$. brassicae and $A$. raphani as against A. brassicicola. The fungi in question are biologically and systematically very close to each other (NEERGAARD 1949). On the basis of this, Streptomyces dressing would appear to be effective against all seed-borne Alternaria fungi on cruciferous plants, as is the case with chemical dressing. However, Phoma lingam can act as a seed-borne pathogen of cruciferous plants (NEERGAARD 1977), and its susceptibility to this biological control method could not be estimated here. Nowadays, however, the fungus does not have to be controlled since it is of no significance as a seed-borne pathogen in seedling production in Finland (TAHVONEN 1979) for which most of the seed material is imported from Sweden, Denmark and Holland. In the experiments carried out here, for instance, none of the 33 seed lots examined was infected by $P$. lingam.

Table 2. Effectiveness of Streptomyces seed dressing in controlling Alternaria brassicicola on cauliflower raised in different types of soil.

\begin{tabular}{|c|c|c|c|c|c|c|}
\hline \multirow[t]{3}{*}{ Seed dressing } & \multicolumn{6}{|c|}{ Type of soil } \\
\hline & Peat & $\begin{array}{c}\text { Steam-sterilized } \\
\text { peat }\end{array}$ & Fine sand & $\begin{array}{c}\text { Fine sand }+ \\
30 \% \text { peat }\end{array}$ & Clay & Mull \\
\hline & \multicolumn{6}{|c|}{ Healthy, viable seedlings } \\
\hline Healthy seeds & $86 a$ & $90 \mathrm{a}$ & $86 a$ & $91 \mathrm{a}$ & $75 \mathrm{a}$ & $85 \mathrm{a}$ \\
\hline Untreated & $26 \mathrm{~b}$ & $35 b$ & $58 \mathrm{~b}$ & $25 \mathrm{~b}$ & $38 \mathrm{~b}$ & $72 \mathrm{a}$ \\
\hline Streptomyces & & & & & & \\
\hline $5 \mathrm{~g} / \mathrm{kg}$ & $84 a$ & $83 a$ & $74 a$ & $85 \mathrm{a}$ & $70 \mathrm{a}$ & $78 \mathrm{a}$ \\
\hline Streptomyces & & & & & & \\
\hline $10 \mathrm{~g} / \mathrm{kg}$ & $79 \mathrm{a}$ & $80 \mathrm{a}$ & $80 \mathrm{a}$ & $86 a$ & $71 a$ & $88 \mathrm{a}$ \\
\hline Thiram & & & & & & \\
\hline $4 \mathrm{~g} / \mathrm{kg}$ & $85 a$ & $83 a$ & $90 \mathrm{a}$ & $80 a$ & $77 \mathrm{a}$ & $85 a$ \\
\hline
\end{tabular}


Viable seedlings

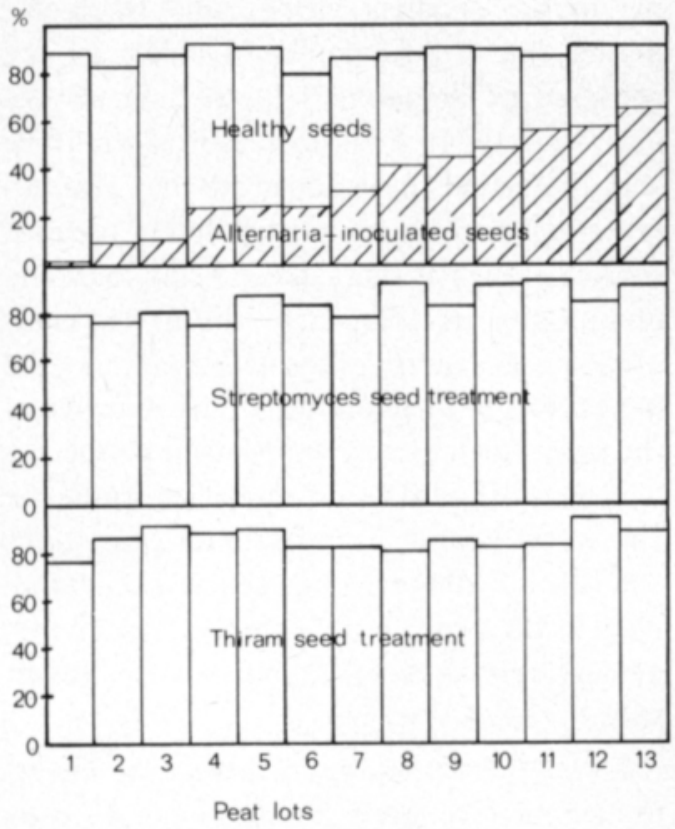

Fig. 6. Effect of seed dressing with thiram or different amounts of the Streptomyces preparation on the control of damping-off caused by Alternaria brassicicola on cauliflower grown in different peat lots. Peat lots: $1=$ steamed peat, $2-13$ peat lots of different origin.

The Streptomyces isolate used in these experiments was strongly antagonistic on agar against all the pathogens tested earlier (Tahvonen 1982 b). Turhan and Grossmann (1986) reported that their Streptomyces isolates were always antagonistic to a number of pathogens if they were strongly antagonistic towards Rhizoctonia and Alternaria. This would indicate that the dressing method employed here could also be effective against other fungi, such as Fusarium spp., Phoma spp. and Stemphylim spp, which are all significant seed-borne fungi on a number of plants (NeERgaARd 1977).

Bacteria proper and Actinomycetes usually thrive best in neutral or slightly alkaline substrates (BAKER and COOK 1974). For this reason, it would be expected that Actinomycetes would be an ineffective biological control agent in acidic substrates such as peat, where the $\mathrm{pH}$ at which cultivation normally takes place is in the range $5.5-6.5$ (PuUst.

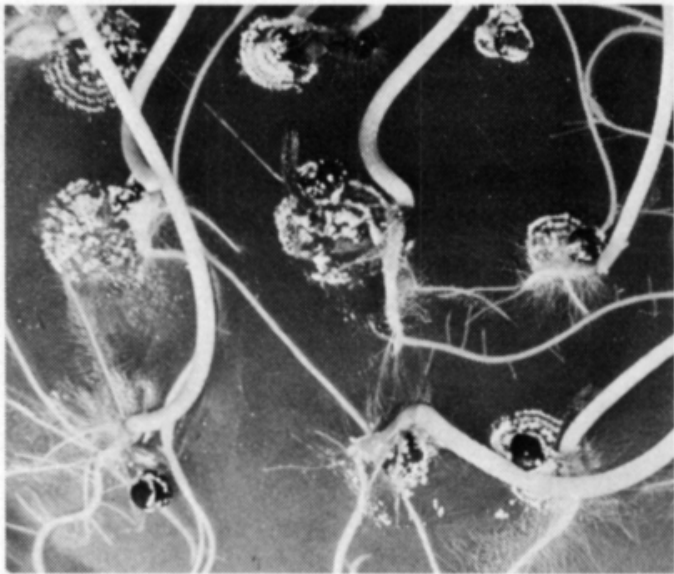

Fig. 7. Growth of Streptomyces sp. on cauliflower seeds and agar.

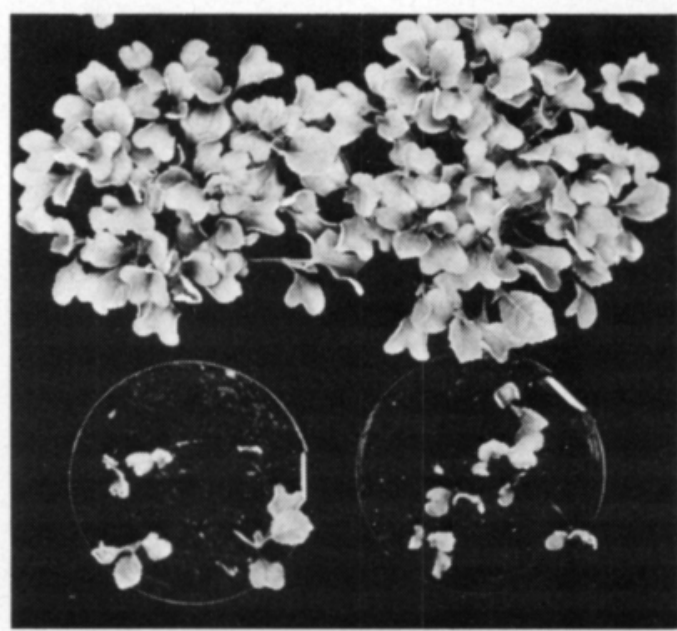

Fig. 8. Control of Alternaria damping-off with Streptomyces seed treatment. At the bottom untreated seeds and at the top seeds treated with Streptomyces-preparate.

JÄRVI 1974). In the experiments described in this paper, the Streptomyces sp. isolated from naturally acidic peat was effective against $\mathrm{Al}$ ternaria over the wide $\mathrm{pH}$ range of $4.8-8.6$. This is a very satisfactory result as regards the practical application of the control method in substrates of varying acidity. However, the question of whether it is a case of Actinomycetes thriving in the favourable conditions of the plants' rhizosphere, or an example of adaptation to different acidity levels in the soil, can only be answered through more detailed investigations. 


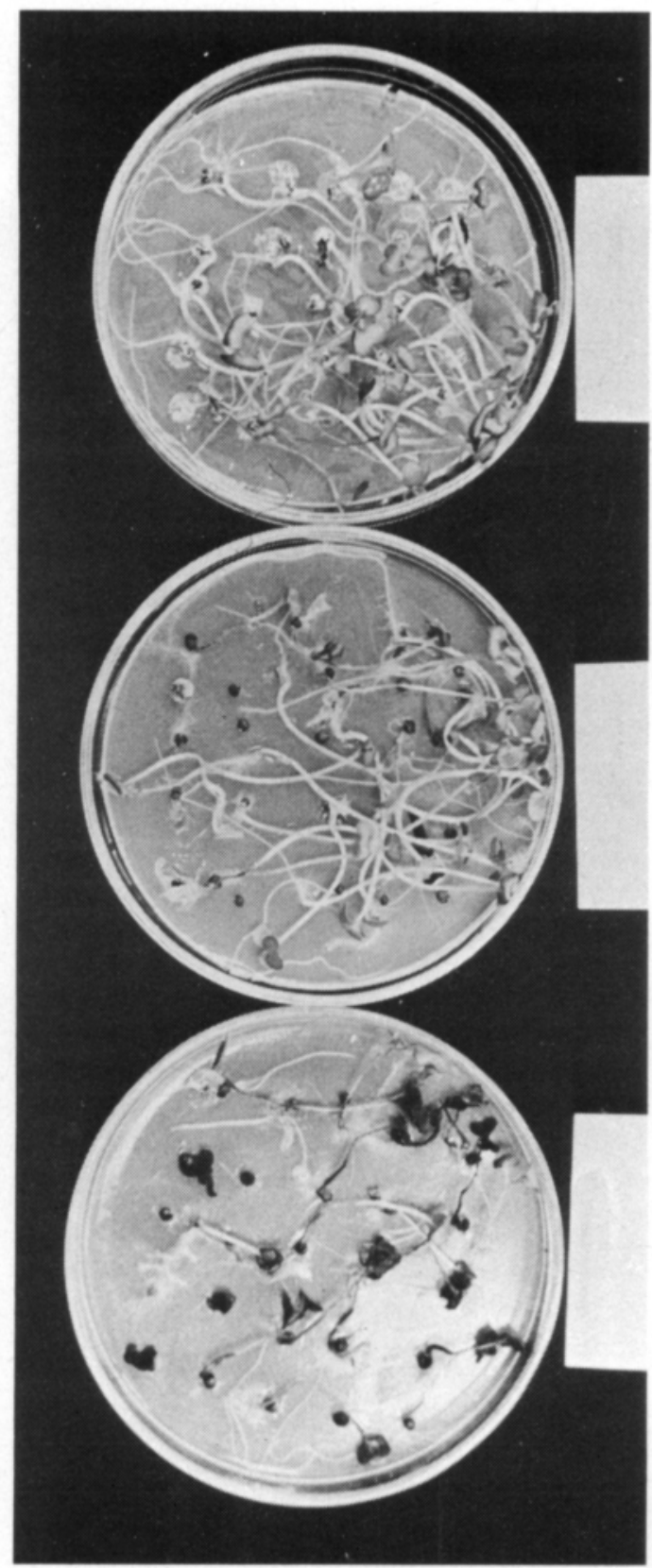

Fig. 9. Effect of Streptomyces and thiram seed treatment on seed-borne Alternaria brassicicola. At the top Streptomyces, in the middle thiram treated seeds and at the bottom naturally infected cauliflower seeds.
The properties of the substrate, especially $\mathrm{pH}$, moisture content, airspace and the organic matter, have a fundamental effect on the activities of antagonists in the soil (BAKER and СоOK 1974). For this reason it would be very important to demonstrate that Streptomyces sp. also functions in different types of substrate, such as fine sand and clay soils, and in mull mixtures. Similarly, the effectiveness of biological control of the pathogen was good in peat lots of different origin, irrespective of the peat's own disease suppressive properties which have been found in earlier studies to vary considerably from lot to lot (TAHVONEN 1982 a). It is obvious that the natural antagonists in the peat do not inhibit the activities of the Streptomyces antagonist carried by the seed.

It has been possible in these experiments to demonstrate, using a wide range of strategies, that the Streptomyces sp. isolated from peat is effective in controlling seed-borne A. brassicicola on Brassica sp. plants. Other antagonists, such as Gliocladium, Trichoderma and Penicillium spp., have also given good results in similar applications (WU and $\mathrm{LU}$ 1984).

Other species of Streptomyces have been successfully used on cabbage (KUNDU and NANDi 1984) and pea (Rothrock and GotTlieb 1984) in the control of Rhizoctonia dampingoff. In preliminary trials the Streptomyces sp. used here also controlled Rhizoctonia damping-off (TAHVonen 1982 b). The Streptomyces antagonist clearly has a good potential in commercial applications as an alternative to the chemical dressing of cruciferous plants. The present results suggest that more extensive applications to other plants and pathogens are also possible (TAHVONEN and UOTI 1983, TAHVONEN 1985). 


\section{References}

BAKER, F.B. \& COOK, R.J. 1974. Biological control of plant pathogens. 433 p. San Francisco.

Dixon, G.R. 1981. Vegetable Crop Diseases. 404 p. Salisbury, Wiltshire.

HeınZE, K. 1974. Leitfaden der Schădlingsbekămpfung. Band I. Schädlinge und Krankheiten im Bemüsebau. 360 p. Stuttgart.

Kundu, P.K. \& Nandi, B. 1984. Control of cauliflower damping-off by using antagonist coated seeds. Pedobiol. 27: $43-48$.

Rothrock, C.S. \& Gottlieb, D. 1984. Rise of antibiosis in antagonism of Streotimyces hygroscopicus var. geldanus to Rhizoctonia solani in soil. Can. J. Microbiol. 30: $1440-1447$.

Maude, R.B., Humpherson, J.F.M. \& Shuring, C.G. 1984. Treatments to control Phoma and Alternaria infections of brassica seeds. Pl. Path. 33: 525-535.

Neergaard, P. 1945. Danish species of Alternaria and Stemphylium. 560 p. Cobenhagen.

- 1977. Seed Patholgy. 1187 p. Surrey.

PuUstנĀrvı, V. 1974. Kasvuturve ja sen käyttö. 172 p. Helsinki.

TAHVONEN, R. 1979. Seed-borne fungi on cruciferous cul- tivated plants in Finland and their importance in seedling raising. J. Scient. Agric. Soc. Finl. 51: 327-379.

-1982 a. The suppressiveness of Finnish light coloured Sphagnum peat. J. Scient. Agric. Soc. Finl. 54: 345-356.

- 1982 b. Preliminary experiments into the use of Streptomyces spp. isolated from peat in the biological control of soil and seed-borne diseases in peat culture. J. Scient. Agric. Soc. Finl. 54: 357-369.

- 1985. Mycostop - ett biologiskt bekămpningsmedel mot svampsjukdomar. Växtskyddsnotiser 49: 86-90, 93.

— \& Uotı, J. 1983. The use of Streptomyces as a biological control agent. $10^{\text {th }}$ Intern. Congr. Pl. Protect. 1983: 2, 795.

Turhan, G. \& Grossmann, F. 1986. Investigation of great number of actinomycete isolates on their antagonistic effect against soil-borne fungal plant pathogens by an improved method. J. Phytopath. 116: 238-243. Wu, V.S. \& Lu, J.H. 1984. Seed treatment with antagonists and chemicals to control Alternaria brassicicola. Seed Sci. and Technol. 12: 851-862.

Ms received August 19, 1987

\section{SELOSTUS}

\section{Alternaria Brassicicola -sienen biologinen torjunta kaalikasvien siemeniltä jauhemaisella Streptomyces-bakteerivalmisteella}

\author{
Risto Tahvonen ja Hanna Avikainen \\ Kasvitautiosasto \\ Maatalouden tutkimuskeskus, \\ 31600 Jokioinen
}

Turpeesta eristetystä Streptomyces-bakteerista valmistettua jauhemaista bio-peittausainetta tutkittiin kaalikasveilla siemenlevintäisen Alternaria brassicicola -sienen torjumiseksi. Valmiste oli tehty fermentaattorissa kasvatetusta biomassasta pakastekuivaamalla ja jauhamalla peittausaineeksi soveltuvaksi pulveriksi, jonka kaupallinen nimi on Mycostop. Ainetta käytettiin peittauksissa $1-15 \mathrm{~g} /$ siemenkilo. Taimipoltteen torjuntatehoa verrattiin kemialliseen tiraami-peittaukseen sekä keinosaastutetuilla ettă luontaisesti saastuneilla siemenillä ravintoalusta ja taimikasvatustestein. Valmisteen biologisen tehokkuuden săilyminen varastoiduilla, peitatuilla siemenillă tutkittiin $0-6 \mathrm{kk}$ peittauksen jälkeen tehdyillä kylvöillă höyrytettyyn turpeeseen. Eri alkuperäă olevien tur- peiden, eri kivennäisalustojen sekä turpeen $\mathrm{pH}: \mathrm{n}$ vaikutusta torjuntatehoon selvitettiin.

Siemenen peittaus Streptomyces-valmisteella torjui $80-90 \%$ :sti taimipoltteen voimakkaasti Alternaria-sienellă saastutetuilta siemeniltă turvealustalla kasvatettuna. Peittauksen teho săilyi kuivana varastoiduilla siemenillă 5-6 viikkoa muuttumattomana, minkă jälkeen teho laski hitaasti ollen noin $50 \% 6$ kk:n kuluttua peittauksesta. Streptomyces-peittaus torjui taimipoltteen samalla tehokkuudella kuin kemiallinen tiraami-peittaus luontaisesti saastuneilta kauppasiemeneriltä. Taimipoltteen biologinen torjuntatulos ei vaihdellut eri alkuperảa olevissa turve-erissă suoritetuissa taimikasvatuksissa, vaikka turpeiden luontainen taudinestokyky vaihteli voimak- 
kaasti. Torjuntatulos oli sama tai parempi kuin kemiallisella tiraami-peittauksella. Kasvualustan happamuudella $\mathrm{pH}$-alueella $4.8-8.6$ ei ollut vaikutusta biologisen peittauksen tehoon. Muissa kasvualustoissa, savi, hieta ja multaseos, oli Alternaria-taimipoltteen torjuntatulos sa- ma kuin turpeessa,

Tehdyt tutkimukset osoittivat, että kaalikasveilla voidaan kemiallinen peittaus korvata biologisella peittausmenetelmällă, joka ei käytănnön toteutukselta kuitenkaan poikkea perinteisistä työtavoista. 